\title{
PERP Gene
}

National Cancer Institute

\section{Source}

National Cancer Institute. PERP Gene. NCI Thesaurus. Code C94766.

This gene plays a role in desmosome assembly and apoptosis. 